\title{
Where the wine is velvet: Verbo-pictorial meta- phors in written advertising
}

Rosa Lídia Coimbra, Helena Margarida Vaz Duarte and Lurdes de Castro Moutinho

Department of Languages and Cultures, University of Aveiro, Portugal

https://doi.org/10.36505/ExLing-2006/01/0019/000019

\begin{abstract}
In this presentation, we intend to approach pictorial metaphors (PM) and verbo-pictorial metaphors (VPM) in written Portuguese advertising, using a corpus of news-paper and magazine advertisements. As theoretical framework, we use the Cognitive Linguistics theory of the multiple spaces and blending by Gilles Fauconnier and Mark Turner (2003) and part of Charles Forceville's (1996) approach to VPM. The collected corpus is analysed, and the main objective of this study is the presentation of a typology for the diverse ways to establish conceptual blending in VPM (Coim-bra, 2000). It is argued that there are at least six categories of VPM.
\end{abstract}

\section{Introduction}

Advertising has a prominent place among the text genres that speakers most frequently read, not only due to its prevalence in mass media, but also in all urban places. Such profusion has led to increasing attempts to catch the attention of the target public, which account for more and more imaginative texts. One original resource consists on the metaphorical reading of the interaction between linguistic elements and images within the advertisement.

The main objective of this study is the presentation of a typology for the diverse ways to establish conceptual blending in VPM (for more details on this typology, cf. Coimbra, 2000).

In spite of accounting for a more comprehensive phenomenon -conceptual blending- the multiple space theoretical model is appropriate to our research since VPM include the fusion of two different input spaces that allow the creation of a blended space where the new emergent reality appears. Our examples illustrate the different processes employed to operate the interaction between input domains in the VPM in written advertisements. It is argued that there are several categories which account for different ways of building and decoding the message and its polissemy.

ExLing 2006: Proceedings of 1st Tutorial and Research Workshop on Experimental Linguistics, 28-30 August 2006, Athens, Greece 


\section{Pictorial metaphors}

The main characteristic of metaphor is that it connects things that were not previously connected, at least not in an obvious way. A conceptual metaphoric link can be expressed in a variety of ways: linguistic metaphors, pictorial metaphors, cinematic metaphors, etc. Forceville (1996: 65) suggests that "an account of pictorial metaphor should show an awareness that a metaphor has two distinctive terms, one primary subject or tenor, the other the secondary subject or vehicle".

Our typology consists of six categories that account for the different processes employed to operate the interaction between input domains in the PM in written advertisements. They are the following:

Table 1. This table shows examples of the different categories of our typology of pictorial metaphors.

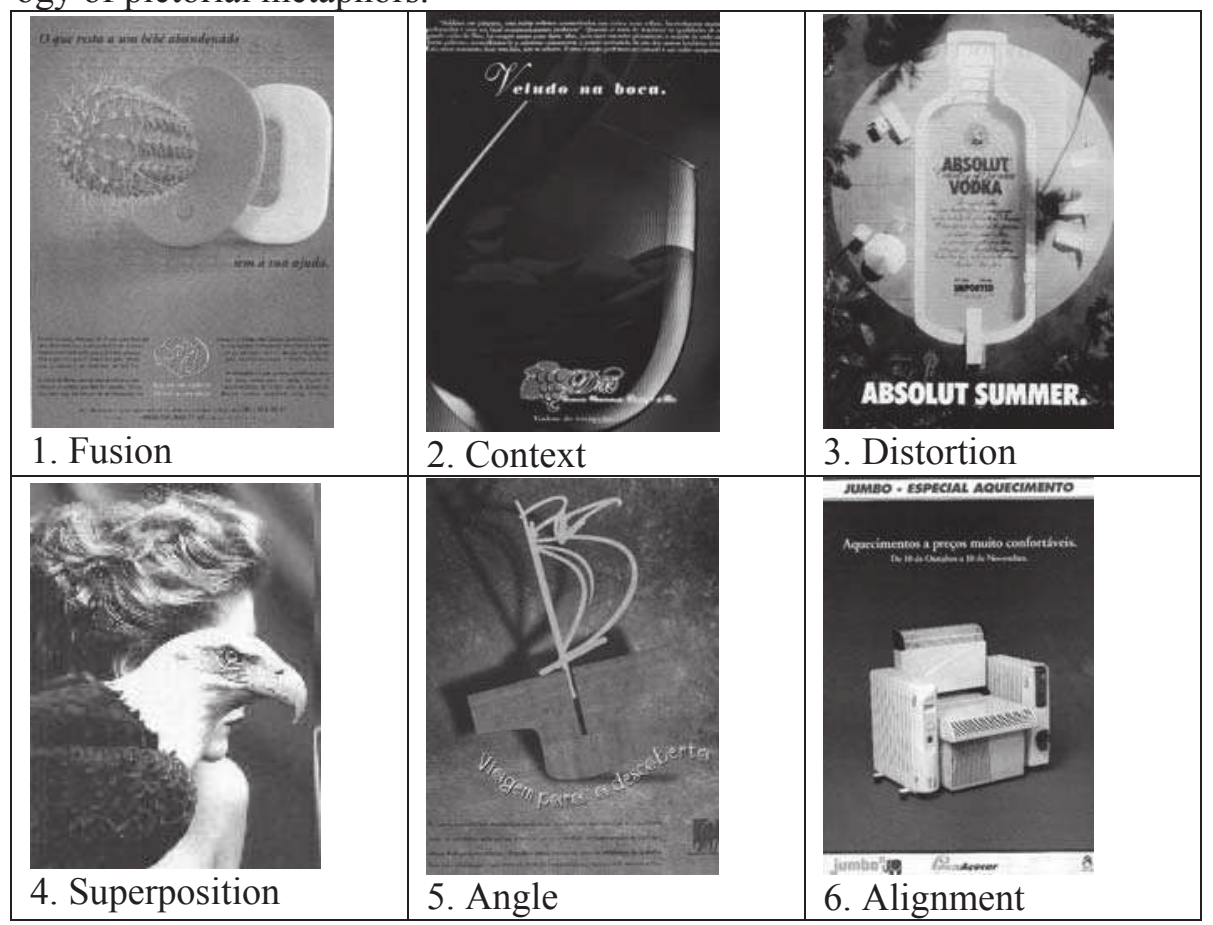

1. Fusion. On this category, we include the cases that Forceville (1996: 109-126) calls MP2s, that is, pictorial metaphors in which the two terms are merged in order to create a new, non previously existing object. The first example in table 1 shows a soother (pacifier) that is visually blended with a cactus full of thorns. The tenor is the soother, since it is an advertisement about an institution that helps abandoned babies. The words that constitute 
the slogan, "What's left to an abandoned baby without your help" explain that the thorns of the cactus mean the extreme suffering these babies feel. The metaphor in very powerful because we can imagine what one of these soothers would do to a baby's delicate mouth.

2. Context. This category includes the examples where the metaphorical reading is not produced by a fusion, but by inserting the vehicle into a context where we would expect the tenor to be. Forceville (1996: 126-132) also studied these cases, which he calls MP1s, and which are characterised by the absence of the tenor (or source domain counterpart, or input space 1, according to Fauconnier and Turner's terminology) which, instead, is suggested by the visual context in which the vehicle (or target domain counterpart, or input space 2) is placed and which is not the one we are used to see it in. The second example in table 1 shows a red velvet cloth placed in a visual context where we would expect red wine to be. The association is obvious: the synaesthetic sensation of smoothness.

3. Distortion. The possibility of processing images by computer software made this category one of the most used in pictorial metaphor. The two objects are captured simultaneously in a pictorial blend. Example 3 of table 1 shows us a blend between a bottle and a swimming pool by changing the latter's typical rectangular shape.

4. Superposition. The fifth category accounts for the examples where the two counterparts are overlapped, so that we think of one in terms of the other. It is the case of the woman in example 4 table 1 whose strategic business capacities are compared to the sharp vision of the eagle.

5. Angle. Another possibility is to present the object of one domain in such a position that reminds us of the angle in which we are used to see the other object. It is the case of the office table in example 5, which is placed as a vessel. The link is underlined by the words: "Voyage to discovery"

6. Alignment. This category includes examples such as 6 where several objects are placed in such a way that they together make the shape of the absent object. In this case, 5 heaters align to form a couch.

\section{Verbo-pictorial metaphors}

Context plays an important role in differentiating pictorial from verbo-pictorial metaphors. Forceville (1996: 159) explains the difference in the following terms: "the subdivision into pictorial and verbo-pictorial metaphors is not an absolute one. (...). If one were to delete all textual material from an advertisement, and the two terms of the metaphor could still be identified, then the metaphor in question is a pictorial metaphor or simile". 


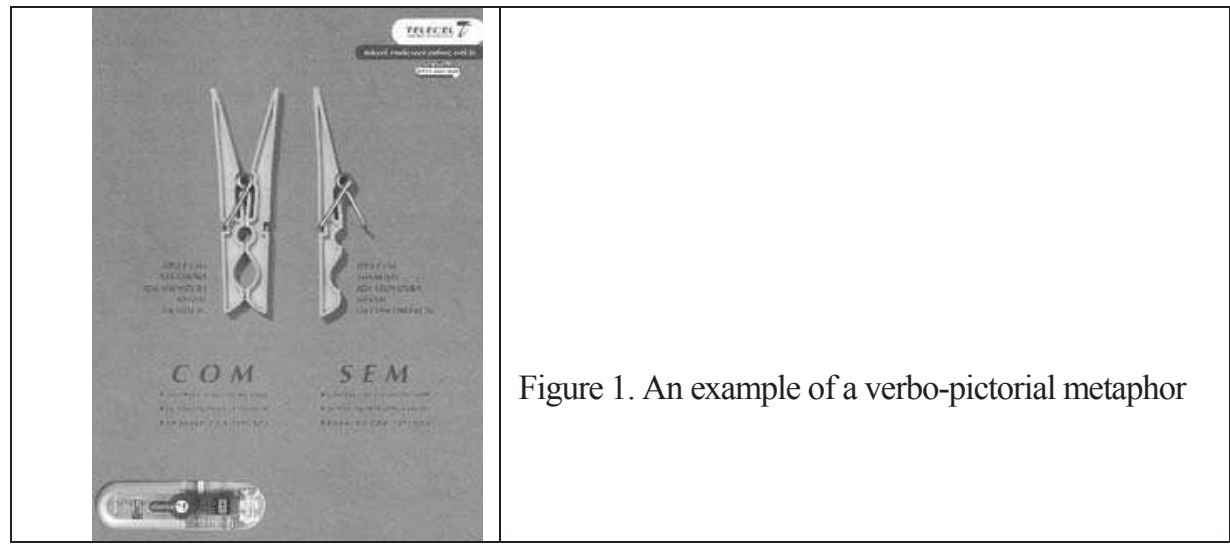

It is not the case of our example in figure 1. Without the linguistic context, the reader would not understand that the picture of the two pegs required a metaphoric interpretation. In fact, the words "With Without" mean that a cell phone may be useful or useless, depending on it having or not the service that is being advertised.

\section{Conclusion}

There are several strategies to make the reader aware of the subtle presence of one of the metaphorical counterpart. In this paper, we presented some of the ways to achieve this goal. Pictorial and verbo-pictorial metaphors are, as we may see, by the examples presented, interesting ways of drawing the reader's attention by placing an unusual reading of both image and text. Due to its pervasiveness, it is a phenomenon that should be the object of the study of discourse analysis. By its complexity, verbo-pictorial metaphors are a challenge to linguists and an open field to new an interesting research.

\section{References}

Coimbra, R. L. 2000. Quando a Garrafa é um Porco: Metáforas (Verbo)Pictóricas no Texto Publicitário. In Castro, R.V. and Barbosa, P. (eds), Actas do XV Encontro Nacional da Associação Portuguesa de Linguística. vol. 1, 243-253, Faro, Portugal.

Fauconnier, G. and Turner, M. 2003. The Way we Think: Conceptual Blending and the Mind's Hidden Complexities. New York, Basic Books.

Forceville, C. 1995. IBM is a tuning fork: Degrees of freedom in the interpretation of pictorial metaphors. Poetics, 23, 189-218.

Forceville, C. 1996. Pictorial Metaphors in Advertising, London/ New York, Routledge. 